Прегледни чланак/Review Paper

\author{
МЕКА КОНТАКТНА СОЧИВА-ОСНОВНЕ \\ КАРАКТЕРИСТИКЕ, ПРЕДНОСТИ И КОМПЛИКАЦИЈЕ \\ КОЈЕ ПРАТЕ ЊИХОВУ ПРИМЕНУ
}

\author{
Милош Милосављевић
}

Факултет медицинских наука, Универзитет у Крагујевцу

\title{
SOFT CONTACT LENSES-BASIC \\ CHARACTERISTICS, ADVANTAGES AND COMPLICATIONS ASSOCIATED WITH THEIR USE
}

\section{Miloš Milosavljević}

Faculty of Medical Sciences, University of Kragujevac

Примљен/Received: 26.11.2015.

Прихваћен/Accepted: 9.2.2016.

\section{САЖЕТАК}

Мека контактна сочива имају значајно место у офталмологији како у корекцији рефракционих аномалија тако и у лечењу неких очних обољења. Од момента када су пронађени довољно биокомпатибилни материјали, за јако осетљиву средину какву представљају људске очи, почетком 60-тих година 20. века, креће незадржива експанзија меких контактних сочива. Разлог оволике експанзије меких сочива лежи у предностима које ова оптичка помагала несумњиво имају и у односу на наочаре, али и у односу на тврда и полу-тврда контактна сочива. Нажалост, паралелно са повећањем броја корисника овог типа оптичких помагала, повећава се и учесталост компликација које могу да се јаве код корисника.

Компликације по својој природи и тежини могу бити веома разноврсне, али се могу сврстати у три велике групе: симптоми сувоће ока, инфекције и алергијско-токсичне компликације. Симптоми сувог ока су веома чести код корисника контактних сочива, а њихову појаву посебно провоцирају одређени фактори, као што су дувански дим или често гледање у екран рачунара или ТВ-а. Ове компликације по правилу нису тако опасне и лако се решавају применом вештачких суза. Инфекције нису тако честе и настају као резултат неадекватног одржавања контактних сочива. Уколико се симптоми препознају на време, инфекције се углавном заустављају на нивоу коњуктивитиса и лече се доста брзо и лако. У супротном, инфекције могу прогредирати до улцерозних кератитиса који представљају најтежу компликацију неадекватне примене меких контактних сочива, а у појединим случајевима могу довести чак и до слепила. Алергијско-токсичне компликације се углавном јављају код предиспонираних особа и ьихова појава у највећем броју случајева представља контраиндикацију за даље ношење меких контактних сочива.

Кључне речи: мека контактна сочива, суво око, инфекција, улцерације рожњаче

\section{ABSTRACT}

Soft contact lenses have an important place in ophthalmology, both for the correction of refractive anomalies and tor the treatment of some eye diseases. From the moment when 
adequately biocompatible materials were found, for a very sensitive environment such as the human eye, from early 60 s of the 20th century, starts irrepressible expansion of soft contact lenses. The reason for this expansion of soft contact lenses lies in advantages they undoubtedly have in comparison to glasses, but also in comparison to hard and semi-hard contact lenses. Unfortunately, in parallel with the increasing number of users of this type of optical aids, increases the incidence of complications that can arise.

Complications can be very diverse in nature and severity, and they can be classified into three major groups: symptoms of eye dryness, infections and allergic-toxic complications. Symptoms of dry eye are very common for users of contact lenses, and their occurrence is especially provoked by certain factors, such as cigarette smoke or prolonged watching the computer screen or TV. These complications are usually not so dangerous and can easily be solved by applying artificial tears. Infections are not so common and occur as a result of inadequate maintenance of contact lenses. If the symptoms are recognized early, infections are mostly stoped at the level of conjunctivitis and are treated fairly quickly and easily. Otherwise, the infection can progress to ulcerative keratitis, the most severe complication of inadequate application of soft contact lenses, and in some cases it can even lead to blindness. Allergic-toxic complications generally occur in susceptible persons and their occurrence in most cases means contraindication for further wearing of soft contact lenses.

This case report underlines possible role of rheumatoid factor in estimation of the patient's response to administered therapy.

Key words: soft contact lenses, dry eye, infection, ulceration of the cornea

\section{ИСТОРИЈАТ РАЗВОЈА КОНТАКТНИХ СОЧИВА}

Први подаци везани за контактна сочива потичу из 16. века. Идејним творцем контактних сочива сматра се велики ренесансни уметник Леонардо да Винчи, за кога се верује да је 1508. године направио прву претечу савремених контактних сочива. Ипак, до развоја првих правих контактних сочива чекало се све до 1912. године, када чувена компанија Carl Zeiss започиње производњу сочива за терапију кератоконуса. Ова сочива су била направљена од веома танког стакла, а наредни револуционарни помак у производњи сочива 1948. године прави оптичар Кевин Тухи, који патентира тврда гас непропусна сочива направљена од полиметилметакрилата или плексигласа ${ }^{1}$. Главни недостатак овог полимера је непропустљивост кисеоника, тако да су последичне хипоксичне реакције рожњаче представљале главни проблем код њихових корисника ${ }^{2}$. У међувремену је проблем везан за непропустљивост кисеоника код тврдих контактних сочива решен кополимеризацијом плексигласа са силиконом односно перфлуорополиетрима, тако да тврда контактна сочива данас имају значајно место у офталмологији ${ }^{3}$. Ипак, најпопуларнија оптичка помагала су мека контактна сочива, за чије откриће су заслужни чешки хемичар Ото Вичтерл и његов сарадник Драхослав Лим, који су шездесетих година 20. века синтетизовали хидроксиетил метакрилат. Новооткривени хидрогел је одговарао захтевима медицине: пластика која се користи је инертна за околна ткива, хемијски и биолошки стабилна, пропустљива за кисеоник и остале метаболите, хидрофилна слично живом ткиву и задржава жељени облик. Током 1971. године фармацеутска компанија Bausch \& Lomb купује лиценцу за производњу меких контактних сочива и од тада креће незаустављиви талас популаризације и масовне примене ових оптичких помагала ${ }^{1}$.

\section{ФИЗИЧКО-ХЕМИЈСКА СВОЈСТВА МЕКИХ КОНТАКТНИХ СОЧИВА}

Најправилнији назив за овај тип сочива јесте хидрофилна (хидрогел) сочива, јер упркос називу „мека”, ова сочива имају својствену чврстину и постојана су хемијски и физички под оптималним условима (изотонија од $\mathrm{pH} 5,5$ до 7,4), отпорна су на истезање (до 2,5 пута) и искувавање (до $120^{\circ} \mathrm{C}$ ) што зависи од материјала и начина производње. Сва мека контактна сочива пропуштају кисеоник, већа су од тврдих сочива, прекривају рожњачу и део беоњаче, теже се губе и имају способност савијања и враћања у првобитни облик. Међутим, она мењају својства у хипертоној, хипотоној, алкалној или киселој средини ${ }^{4}$. Сви типови меких контактних сочива садрже извесни проценат воде у свом саставу (30-90\%). Из тог разлога, на сувом постају чврста после пар минута услед губитка течности (дехидратације) и могу се сломити или смрвити. Зато мека сочива, када нису у оку, морају бити у физиолошком 
раствору или растворима за одржавање меких контактних сочива које је произвођач одредио 5 .

\section{ТИПОВИ МЕКИХ КОНТАКТНИХ СОЧИВА}

Постоји неколико различитих параметара на основу којих је могуће извршити класификацију меких контактних сочива ${ }^{6}$. Ипак, најважнија класификација меких контактних сочива везана је за дужину њихове препоручене континуиране примене, која је највећим делом условљена степеном пропустљивости кисеоника ${ }^{4}$. Тако разликујемо сочива за:

- Дневно ношење - сочива се носе дању, а скидају увече пред спавање

- Продужено ношење - ношење сочива током дана и ноћи (7 дана и 6 ноћи)

- Континуирано вишедневно ношење ношење током дана и ноћи (30 дана и 29 ноћи)

- Флексибилно ношење - ношење сочива током дана и повремено током ноћи (компромис између дневног и продуженог ношења).

Последњих година нарочито су популарна сочива која се могу континуирано без скидања носити у дужем временском периоду. Ова сочива спадају у групу силикон-хидрогел сочива, јер се посебном техником хибридизације пропустљивост хидроксиетил метакрилата повећава додавањем силикона. Велики број научних радова указује да силикон-хидрогел сочива својим корисницима пружају већи комфор и бољи субјективни вид у поређењу са конвенционалним меким контактним сочивима $^{7}$. Силикон-хидрогел сочива несумњиво представљају савршенију верзију меких контактних сочива, а због своје велике пропустљивости према кисеонику популарно се називају и „сочива која дишу”“. Једна од значајнијих предности коју са собом носи примена силикон-хидрогел сочива је изостанак појаве васкуларизације рожњаче и перилимбалне хиперемије очију, која се јавља код одређеног броја корисника меких контактних сочива $^{8}$. Као највећа мана ових сочива тренутно се апострофира њихова цена, због чега ова оптичка помагала знатно спорије освајају економски сиромашнија тржишта ${ }^{4}$.

\section{ПРЕДНОСТИ КОЈЕ ПРУЖАЈУ МЕКА КОНТАКТНА СОЧИВА}

Број корисника меких контактних сочива је у перманентном порасту. Подаци указују да данас има између 111 и 114 милиона корисника меких контактних сочива, али је тај број сигурно већи због могућности да се сочива набаве путем Интернета, а у земљама развијеног света чак и у свим већим и боље снабдевеним супермаркетима. Разлог оволике експанзије меких сочива лежи у огромним предностима које она несумњиво имају у односу на наочаре, али и у односу на тврда и полутврда контактна сочива 9

Када се говори о корекцији кратковидости (миопије), односно далековидости (хиперопије), мека контактна сочива имају значајне предности у односу на конкурентна оптичка помагала - наочаре и тврда сочива. Важна предност контактних сочива у односу на наочаре је ширина видног поља, јер сочива обезбеђују неометан периферни вид што је изузетно важно за возаче, фотографе, спортисте, али и за свакодневне активности ${ }^{10}$. Код појединих болести ока, као што су одређени типови астигматизма, изразито високе диоптрије, применом меких контактних сочива се постиже боља видна штрина ${ }^{11}$. Важну групу корисника контактних сочива чине пацијенти код којих постоје велике разлике у диоптрији измећу два ока - анисометропија (по правилу све разлике веће од 3 диоптрије). Код ових пацијената рефракционе грешке не могу бити решене применом наочара, па је то пример апсолутне медицинске индикације за примену контактних сочива. Контактна сочива своде на минимум и друге оптичке недостатке наочара: нема сферне и хроматске аберације, нема призматског деловања сочива, а такође изостаје деформација равних површина ${ }^{12}$. Поред ових чисто медицинских индикација, постоји читав низ, првенствено естетских разлога, због којих се пацијенти данас одлучују за примену меких контактних сочива. Естетика и задржавање природног изгледа су доминантан разлог због којег се адолесценти одлучују да своје рефракционе грешке коригују применом меких контактних сочива ${ }^{4}$. Сем тога, данас постоје и обојена контактна сочива која са успехом могу да маскирају непигментовану или деформисану дужицу и пупилу ${ }^{12}$.

Мека контактна сочива имају значајне предности и у односу на тврда контактна сочива. Пацијенти се много лакше навикавају 
на мека него на тврда контактна сочива, период адаптације је значајно краћи, а чести проблеми корисника тврдих контактних сочива, као што су фотофобија, сузење и халои око светлосних извора, неупоредиво су ређи код корисника меких контактних сочива ${ }^{4}$.

\section{НЕДОСТАЦИ МЕКИХ КОНТАКТНИХ СОЧИВА}

Мека контактна сочива имају значајна ограничења и недостатке. Често се код пацијената могу јавити хипоксични проблеми, који се најчешће манифестују симптомима сувог ока или појавом васкуларизације рожњаче ${ }^{12}$. Због одређеног процента воде који садрже, мека сочива су јако подложна адхезији различитих честица, услед чега долази до формирања протеинских депозита на њиховој површини. Протеински депозити смањују видљивост, а могу и да предиспонирају појаву инфекција, па је неопходно њихово редовно уклањање са површине сочива. Ако се мека сочива не одржавају исправно и редовно, могућност инфекције рожњаче је повећана. Процедура чишћења и дезинфекције меких сочива је компликованија од одржавања тврдих сочива. Мека сочива су, такође, подложнија механичким оштећењима и неопходно је њихово чешће мењање, што додатно повећава ионако релативно високу цену њиховог коришћења ${ }^{4}$. Сам поступак постављања и скидања контактних сочива може бити веома компликован и стресан, нарочито код старих особа, што је такође озбиљно ограничење њихове примене ${ }^{12}$.

\section{КОМПЛИКАЦИЈЕ КОД КОРИСНИКА МЕКИХ КОНТАКТНИХ СОЧИВА}

Компликације које се могу јавити код корисника меких контактних сочива по својој природи, озбиљности и разлозима појављивања могу бити веома различите, али се генерално могу разврстати у три велике групе: симптоми сувог ока, инфекције и алергијскотоксичне компликације 9

\section{СИМПТОМИ СУВОГ ОКА}

Познато је да су пацијенти који користе мека контактна сочива под већим ризиком за развој симптома сувог ока ${ }^{13}$. Велики број научних радова се бавио анализом ове релације тако да је чак и усвојен један појам за симптоме који се очекивано јављају на крају дана, након вишечасовног континуираног ношења контактних сочива- end-of-day soft lens symptoms ${ }^{14}$. Заступљеност симптома сувог ока није подједнака код свих корисника контактних сочива, већ постоје пацијенти који су једноставно осетљивији од других и којима сувоћа представља веома велики проблем, у смислу да им је сам комфор који су желели да постигну применом меких контактних сочива значајно смањен ${ }^{15}$. Поред тога, појаву симптома сувог ока додатно провоцирају и употреба компјутера, читање, гледање TB-a, загађења ваздуха, дувански дим, сува клима, ветар, централно грејање, вожња, алкохол, пилуле за контрацепцију, антихистаминици и бројни други предиспонирајући фактори ${ }^{16-18}$. Поред тога што смањују комфор, симптоми сувог ока представљају и један од путева који може провоцирати настанак инфекција ока, па их зато треба третирати применом вештачких суза које не садрже конзервансе ${ }^{19}$. Саветује се да корисници меких контактних сочива обавезно поседују и наочаре, које ће носити када из било ког разлога не носе своја сочива ${ }^{4}$.

\section{ИНФЕКЦИЈЕ ОКА}

Инфекције ока се код корисника меких контактних сочива јављају знатно ређе од симптома сувог ока. Ипак, у случају њиховог неблаговременог и неадекватног лечења могу се јавити корнеалне улцерације које чак могу довести до слепила, а које представља потенцијално најтежу компликацију са којом се могу сусрести корисници меких контактних сочива. Код корисника меких контактних сочива постоји велики број фактора који могу да провоцирају појаву инфекција различитих сегмената ока 9 .

Сва питања везана за правилан однос корисника према сочивима, растворима за одржавање сочива и кутијицама за њихово чување су детаљно обрађена од стране америчке Савезне управе за храну и лекове (Food and Drug Administration- FDA). Према препорукама које се налазе на званичној странци FDA (20), апсолутни предуслов за безбедну примену меких контактних сочива је максимална хигијена руку. Пре било каквог контакта са сочивима неопходно је детаљно прање руку од стране корисника. Саветује се употреба течних сапуна, јер на чврстим сапунима могу заостати различити микроорганизми који могу изазвати озбиљне компликације корисницима меких контактних сочива. Сушење руку треба да буде темељно, јер је 
ризичан сваки потенцијални контакт воде са сочивима. У сврхе сушења саветује се употреба једнократних убруса или пешкира, направљених од материјала који не остављају честице тканине на рукама, зато што честице тканине могу да адхерирају на површину сочива и да касније изазивају озбиљне симптоме дискомфора код корисника. Свако евентуално непридржавање ових препорука значајно повећава ризик за развој бројних компликација.

Због поменутих хидрофилних својстава меких контактних сочива неопходно је чувати их у одговарајућем раствору у тренуцима када се не налазе на очима корисника. Поред тог основног разлога за постојање такве течности врло брзо су уочени и бројни други практични разлози. Мека контактна сочива у себи садрже одређени проценат воде због чега су јако подложна адхезији различитих честица за своју површину. Честице делом потичу из сузног филма самих корисника, a други део честица, као што су честице прашине, дуванског дима, али и бројни микроорганизми из ваздуха такође адхерирају за површину контактних сочива. Тако настају протеински депозити који с једне стране смањују видљивост корисника, а с друге стране представљају велики ризик за настанак инфекција ${ }^{21}$. Неопходно је обавезно испирање сочива после сваког њиховог скидања. Када су у питању раствори за одржавање меких контактних сочива, препоруке FDA су веома стриктне, будући да течности представљају погодну средину за развој микроорганизама. FDA изричито наглашава потребу за избегавањем било каквог вида финансијске уштеде када су у питању раствори за одржавање сочива: раствор у кутијицама треба мењати приликом сваког коришћења контактних сочива; растворе треба користити само у оквиру рока трајања и не треба их никако разблаживати водом да би се добило на њиховом волумену ${ }^{22}$. Било какво одступање од поменутих савета FDA са собом носи огроман ризик од могућег развоја инфекција ока. Колико је питање везано за растворе за одржавање меких контактних сочива осетљиво најбоље показује случај из априла 2006. године. Тада је фармацеутска компанија Bausch and $L o m b$ у сарадњи са FDA повукла са тржишта свој раствор за одржавање меких контактних сочива - ReNu with MoistureLoc, због компликација које су се јавиле код великог броја пацијената 9 . Наиме, у самом раствору пронађена је гљивица из рода Fusarium, која је код корисника доводила до појаве фунгалног кератитиса, и појаве слепила код неких пацијената ${ }^{23}$.

Веома је важна и хигијена кутијица у којима се сочива чувају. Резултати до којих су дошли одређени истраживачки тимови ${ }^{24-25}$ указују да у случајевима неажурног и неадекватног чишћења ових посудица долази до формирања бактеријских колонија на њиховим ободима. Из тих разлога неопходно је недељна стерилизација поменутих посудица и њихова редовна замена најкасније на свака три месеца ${ }^{26}$.

Вода представља погодну средину за развој микроорганизама. Сваки евентуални контакт воде са сочивима омогућава микроорганизимима из воде адхезију за површину контактног сочива. Резултати истраживачких тимова и сазнања којима располаже FDA указују на посебну опасност од инфекција које код корисника меких контактних сочива изазива Acanthamoeba, која има способност преживљавања у хлорисаној води ${ }^{27-28}$. FDA корисницима меких контактних сочива изричито забрањује могућност пливања без примене адекватних заштитних наочара ${ }^{20}$.

Инфекције ока код корисника меких контактних сочива најчешће нису озбиљније природе и у случају благовременог дијагностиковања и отпочињања лечења не представљају контраиндикацију за даље ношење сочива. У случају појаве хиперемије или других симптома иритације FDA препоручује корисницима да без одлагања скину своја контактна сочива и обрате се офталмологу. У највећем броју случајева инфекције се заустављају на нивоу конјунктивитиса и успешно се третирају применом одговарајућих антибиотских капи или масти. За време трајања терапије пацијенти не смеју носити своја контактна сочива ${ }^{26}$. Међутим, уколико пацијенти не поступе у складу са наведеним препорукама FDA, инфекција обично прогредира до појаве корнеалних улцерација․ Корнеалне улцерације се по правилу развијају када дође до настанка било каквог прекида или пукотине у епителу рожњаче. У нормалним условима, површина рожњаче се константно подмазује сузама. Међутим, када се мека сочива носе континуирано током ноћи, онемогућено је нормално физиолошко лучење суза, а самим тим и адекватно снабдевање рожњаче кисеоником. Последична хипоксија и хиперкапнија изазивају исхемијску некрозу. Настале пукотине касније бивају колонизоване неким 
сојевима микроорганизама и долази до развоја озбиљних инфекција ${ }^{29}$. Колика ће бити дубина поменутих улцерација зависи од великог броја фактора, а најважнији су патогеност самог микроорганизма и време које пацијент проведе пре него што се обрати офталмологу. $\mathrm{У}$ последњих 30 година више од $50 \%$ свих улцерозних кератитиса је регистровано код корисника меких контактних сочива, а најновији подаци такође не охрабрују, будући да број случајева улцерозног кератитиса код корисника меких контактних сочива драматично расте (30). Посебно обесхрабрујуће делују подаци који указују да силикон-хидрогел сочива (која пропуштају кисеоник у много већој мери) не смањују ризик од појаве улцерозних кератитиса у поређењу са конвенционалним меким контактним сочивима ${ }^{31}$.

Узрочници кератитиса могу бити различити микроорганизми, а нарочито тешке форме кератитиса изазивају Pseudomonas aeruginosa и Acanthamoeba. Ови микроорганизми брзо разарају ћелије епитела рожњаче, дајући слику болног прогредирајућег кератитиса који не реагује на уобичајену антимикробну терапију. Дужина лечења кератитиса код корисника меких контактних сочива зависи од великог броја фактора. Уколико је реч о најтежим формама кератитиса, чији су узрочници Pseudomonas aeruginosa или Acanthamoeba лечење може да траје месецима, при чему је у терапију неопходно укључити топикалне форме метронидазола (сматра се да је најефикаснији за лечење кератитиса који узрокује Acanthamoeba), али и топикалне форме левофлоксацина, тобрамицина или неких других антибиотика који су ефикасни против Pseudomonas-a (зависно од резултата антибиограма $)^{32}$. Ефикасност антибиотске терапије код пацијената са кератитисом је углавном задовољавајућа, али у најтежим случајевима патогени потенцијал микроорганизама је довољно велики тако да могу остати ожиљци на рожњачи, услед чега вид пацијента може бити трајно ослабљен. У већини случајева појава улцерација на рожњачи представља трајну контраиндикацију за даље ношење контактних сочива. Уколико пацијенти са улцерозним кератитисом наставе са применом меких контактних сочива може доћи до развоја слепила, као што је описано у једној студији ${ }^{33}$.

\section{АЛЕРГИЈСКО-ТОКСИЧНЕ КОМПЛИКАЦИЈЕ}

Алергијско-токсичне компликације које се могу јавити код корисника меких контактних сочива се према неким ауторима називају и имунолошким компликацијама, јер се сматра да се у основи ових компликација налази имунолошки одговор организма. У ову групу компликација се убрајају стерилни инфилтрати рожњаче, гигантопапиларни коњуктивитис, а по неким ауторима и процеси васкуларизације рожњаче. У случају развоја алергијско-токсичних компликација у епителу вежњаче се може пронаћи велики број дегранулисаних мастоцита 9 . Гигантопапиларни коњуктивитис, услед појаве папила на вежњачи, има за последицу дислокацију меких контактних сочива и немогућност њиховог даљег ношења (34). Инфилтрати рожњаче су релативно честа компликација код корисника меких контактних сочива и могу се класификовати у неколико група, у зависности од тежине и озбиљности њихове појаве. Они могу бити клинички значајни и симптоматски (инфилтративни кератитис, акутно црвенило ока) и клинички без значаја, односно асимптоматски ${ }^{35}$.

Васкуларизација рожњаче и перилимбална хиперемија су компликације које се сврставају у групу имунолошких, иако имунолошком механизму који је одговоран за последичне промене на рожњачи претходи дејство неког спољашњег окидача. Најчешће, услед прекомерног континуираног ношења сочива долази до хипоксије рожњаче, која у физиолошким условима представља неваскуларизовани део ока, што се кисеоником и хранљивим материјама највећим делом снабдева из сузног филма. У таквим условима имуни систем човека реагује процесом васкуларизације рожњаче, формирањем густе мреже капилара који требају да надоместе пре свега кисеоник, али и хранљиве материје потребне за нормално функционисање рожњаче 9 . Услед тога долази до перилимбалне хиперемије рожњаче. Овај проблем се успешно може спречити чешћим скидањем сочива и одмарањем ока. Међутим, пацијентима који желе вишедневну континуирану примену сочива саветује се коришћење силикон-хидрогел сочива, која се одликују далеко већом пропустљивошћу кисеоника. Резултати бројних истраживања указују да се васкуларизација рожњаче и последична перилимбална хиперемија далеко ређе јављају код корисни- 
ка силикон-хидрогел сочива у поређењу са конвенционалним хидрофилним сочивима ${ }^{36-37}$.

\section{КОНТРАИНДИКАЦИЈЕ ЗА ПРИМЕНУ МЕКИХ КОНТАКТНИХ СОЧИВА}

Контраиндикације за примену меких контактних сочива могу бити релативне и апсолутне. Релативне контраиндикације су по правилу привремене и временски ограничене, што значи да особа може да настави са применом сочива када се елиминише фактор контраиндикације, док су апсолутне контраиндикације такве да се фактор који узрокује контраиндикацију не може елиминисати, што подразумева доживотну немогућност примене сочива.

Важну групу релативних контраиндикација за примену меких контактних сочива чине одређене болести ока, као што су акутне или субакутне инфламације појединих сегмената ока, акутне и хроничне инфекције ока, неконтролисани глаукоми. Професионални услови, као што су рад у задимљеним и прашњавим просторијама, изложеност различитим хемикалијама, такође често диктирају немогућност примене меких контактних сочива. Релативне контраиндикације могу бити и одређене болести (реуматоидни артритис, хемиплегије, Паркинсонова болест) које отежавају процес руковања са меким контактним сочивима.

Најважније апсолутне контраиндикације за примену меких контактних сочива везане су за постојање било какве системске или алергијске болести која утиче на око и која се може погоршати применом сочива. Мека контактна сочива се такође не прописују малој деци, старим особама, као ни особама које не воде довољно рачуна о хигијени својих руку ${ }^{38}$.

\section{ЗАКЉУЧАК}

Тешке рефракционе аномалије, као што су анизометропија и различите форме астигматизма данас се успешно коригују применом меких контактних сочива. Важну групу корисника меких контактних сочива чине и кратковиде, односно далековиде особе које мека контактна сочива бирају уместо наочара због боље видне оштрине и периферног вида. Материјали од којих се израђују мека контактна сочива су све савршенији па је и комфор који мека контактна сочива нуде својим корисницима већи. Међутим, ова оптичка помагала су својим корисницима доступна и изван одговарајућих медицинских установа, што може бити опасно с обзиром на озбиљност потенцијалних компликација које прате њихову примену. С обзиром да се може очекивати да ће се тенденција повећања броја корисника меких контактних сочива наставити, у циљу превенције могућих компликација неопходно је побољшати едукацију корисника о свим аспектима правилног одржавања меких контактних сочива.

\section{ЗАХВАЛНИЦА}

Посебну захвалност дугујем проф.др Слободану Јанковићу на искреним саветима и сугестијама приликом израде рада.

\section{РЕФЕРЕНЦЕ}

1. Wegener F. Über generalisierte, septische Gefäßerkrankungen. Verh Dtsch Ges Pathol 1936, 29: 20210

2. Siviglia N. The history of contact lenses. 1st ed. Lancaster: Edward Hand medical heritage foundation; 2010.

3. Ковач Љ. Тврда (гас пропусна и гас непропусна) контактна сочива. Очна кућа ВИЗИЈА. (Посећено у новембру 2015. године на http://www.ocnakucavizija.rs/stranice/tvrdasociva.php).

4. Perrigin J, Perrigin D, Quintero S, Grosvenor T. Silicone-acrylate contact lenses for myopia control: 3year results. Optom Vis Sci. 1990; 67(10): 764-9.

5. Ковач Љ. Мека контактна сочива. Очна кућа ВИЗИЈА. (Посећено у новембру 2015. године на http://www.ocnakucavizija.rs/stranice/mekasociva.php)

6. Green JA, Phillips KS, Hitchins VM, et al. Material properties that predict preservative uptake for silicone hydrogel contact lenses. Eye Contact Lens. 2012; 38(6): 350-7.

7. Food and Drug Administration. Medical Devices. Contact lenses. Types of contact lenses. (Посећено у новембру 2015. године на http://www.fda.gov/ MedicalDevices/ProductsandMedicalProcedures/Home HealthandConsumer/ConsumerProducts/ContactLense s/ucm062319.htm).

8. Tighe BJ. A decade of silicone hydrogel development: surface properties, mechanical properties, and ocular compatibility. Eye Contact Lens. 2013; 39(1): 4-12.

9. Sweeney DF. Have silicone hydrogel lenses eliminated hypoxia? Eye Contact Lens. 2013; 39(1): 53-60.

10. Сувајац Г. Компликације настале ношењем меког контактног сочива. Војносанитетски преглед. 2008; 65(1): 15-20.

11. Varikooty J, Keir N, Richter D, Jones LW, Woods C, Fonn D. Comfort response of three silicone hydrogel daily disposable contact lenses. Optom Vis Sci. 2013; 90(9): 945-53.

12. Fournié P, Touboul D, Arné JL, Colin J, Malecaze F. [Keratoconus]. J Fr Ophtalmol. 2013; 36(7): 618-26.

13. Yildiz EH, Erdurmus M, Elibol ES, Acar B, Vural ET. Contact lens impact on quality of life in keratoconus 
patients: rigid gas permeable versus soft siliconehydrogel keratoconus lenses. Int J Ophthalmol. 2015; 8(5): 1074-7.

14. Pili K, Kaštelan S, Karabatić M, Kasun B, Čulig B. Dry eye in contact lens wearers as a growing public health problem. Psychiatr Danub. 2014;26 (Suppl 3): 528-32.

15. McMonnies CW. Psychological and other mechanisms for end-of-day soft lens symptoms. Optom Vis Sci. 2013;90(6):e175-81.

16. Tran N, Graham AD, Lin MC. Ethnic differences in dry eye symptoms: effects of corneal staining and length of contact lens wear. Cont Lens Anterior Eye. 2013;36(6): 281-8.

17. Kastelan S, Lukenda A, Salopek-Rabatić J, Pavan J, Gotovac M. Dry eye symptoms and signs in long-term contact lens wearers. Coll Antropol. 2013;37 (Suppl 1): 199-203.

18. Khaireddin R. [Contact lens associated dry eye. Current study results and practical implementation]. Ophthalmologe. 2013;110(6): 511-4.

19. Sengor T, Aydin Kurna S, Ozbay N, Ertek S, Aki S, Altun A. Contact lens-related dry eye and ocular surface changes with mapping technique in long-term soft silicone hydrogel contact lens wearers. Eur J Ophthalmol. 2012;22 (Suppl 7): S17-23.

20. McDonald M, Schachet JL, Lievens CW, Kern JR. Systane ${ }^{\circledR}$ ultra lubricant eye drops for treatment of contact lens-related dryness. Eye Contact Lens. 2014; 40(2): 106-10.

21. Food and Drug Administration. Medical Devices. Contact lenses. Everyday Eye Care. (Посећено у новембру 2015. године на http://www.fda.gov/ MedicalDevices/ProductsandMedicalProcedures/Home HealthandConsumer/ConsumerProducts/ContactLense s/ucm062594.htm)

22. Omali NB, Zhao Z, Zhu H, Tilia D, Willcox MD. Quantification of individual proteins in silicone hydrogel contact lens deposits. Mol Vis. 2013;19:390-9.

23. Food and Drug Administration. Medical Devices. Contact lenses. Contact lens solutions and products. (Посећено у новембру 2015. године на http://www.fda.gov/MedicalDevices/ProductsandMedi calProcedures/HomeHealthandConsumer/ConsumerPr oducts/ContactLenses/ucm062584.htm).

24. Food and Drug Administration. Medical Devices. Contact lenses. Advice for Patients With Soft Contact Lenses:New Information on Risk of Serious Fungal Infection. (Посећено у новембру 2015. године на http://www.fda.gov/MedicalDevices/Safety/Alertsand Notices/PatientAlerts/ucm064709.htm).

25. Furuhata K, Ishizaki N, Kawakami Y, Fukuyama M. Bacterial contamination of stock solutions in storage cases for contact lens, and the disinfectant-resistance of isolates. Biocontrol Sci. 2010; 15(3): 81-5.
26. Üstüntürk M, Zeybek Z. Microbial contamination of contact lens storage cases and domestic tap water of contact lens wearers. Wien Klin Wochenschr. 2012; 124 (Suppl 3): 17-22.

27. Food and Drug Administration. Medical Devices. Contact lenses. Contact Lens Risks. (Посећено у новембру 2015. године на http://www.fda.gov/ MedicalDevices/ProductsandMedicalProcedures/Home HealthandConsumer/ConsumerProducts/ContactLense s/ucm062589.htm).

28. Legarreta JE, Nau AC, Dhaliwal DK. Acanthamoeba keratitis associated with tap water use during contact lens cleaning: manufacturer guidelines need to change. Eye Contact Lens. 2013; 39(2): 158-61.

29. Sengor T, Kurna SA, Altun A, Irkec M, Aki SF, Aksoy S. Contact Lens-Related Acanthamoeba Keratitis and Accompanying Dacryoadenitis. Eye Contact Lens. 2015; 41(4): 204-9.

30. Abdelkader A. Cosmetic soft contact lens associated ulcerative keratitis in southern Saudi Arabia. Middle East Afr J Ophthalmol. 2014; 21(3): 232-5.

31. Yildiz EH, Airiani S, Hammersmith KM, et al. Trends in contact lens-related corneal ulcers at a tertiary referral center. Cornea. 2012; 31(10): 1097-102.

32. Evans DJ, Fleiszig SM. Microbial keratitis: could contact lens material affect disease pathogenesis? Eye Contact Lens. 2013; 39(1): 73-8.

33. Hong J, Ji J, Xu J, Cao W, Liu Z, Sun X. An unusual case of Acanthamoeba Polyphaga and Pseudomonas Aeruginosa keratitis. Diagn Pathol. 2014; 9:105.

34. Siddiqui R, Chaudhry T, Lakhundi S, Ahmad K, Khan NA. Failure of chemotherapy in the first reported cases of Acanthamoeba keratitis in Pakistan. Pathog Glob Health. 2014; 108(1): 49-52.

35. Sorbara L, Jones L, Williams-Lyn D. Contact lens induced papillary conjunctivitis with silicone hydrogel lenses. Cont Lens Anterior Eye. 2009; 32(2): 93-6.

36. Sweeney DF, Jalbert I, Corey M, et al. Clinical characterization of corneal infiltrative events observed with soft contact lens wear. Cornea. 2003; 22(5): 43542.

37. Guillon M, Maïssa C. Long-term effects of the daily wear of senofilcon A silicone hydrogel contact lenses on corneal and conjunctival tissues. Optometry. 2010; 81(12): 680-7.

38. Morgan PB, Chamberlain P, Moody K, MaldonadoCodina C. Ocular physiology and comfort in neophyte subjects fitted with daily disposable silicone hydrogel contact lenses. Cont Lens Anterior Eye. 2013; 36(3): 118-25.

39. Lima CA, Kara-Jose N, Nichols JJ. Indications, Contraindications and Selection of Contact Lenses. In: Mannis MJ, Zadnik K, Coral-Ghanem C, Kara-Jose N. Contact Lenses in Ophtalmic Practise. 1st ed. New York: Springer-Verlag, 2004: 7-17. 